tion in which to carry on their work, which, though entirely different in character in the two cases, is of great importance to the nation, the situation will before long require reconsideration, as new conditions have arisen since the arrangement was entered into in 1903 .

\section{BALTIMORE MEETING OF THE AMERICAN} ASSOCIATION.

THE sixtieth annual meeting of the American Association for the Advancement of Science and of the several affiliated societies was held at Baltimore, Md., on December 28, 1908, to January 2, 1909. In practically all respects the meeting was the most successful in the history of the association. It was the largest meeting ever held, and the total attendance is estimated at about 1800 . In addition to the several sections of the association, important meetings were held by the following bodies:-

The American Society of Naturalists, the American Society of Biological Chemists, the American Anthropological Association, the American Folk-lore Society, the American Philosophical Association, the American Physical Society, American Psychological Association, American Physiological Society, American Society of Vertebrate Palæontologists, the American Chemical Society, American Society of Zoologists, American Nature-study Society, American Mathematical Society, the American Federation of Teachers of the Mathematical and the Natural Sciences, American Institute of Electrical Engineers, American Alpine Club, Association of American Geographers, Association of Economic Entomologists, the Botanical Society of America, the Entomological Society of America, Geological Society of America, Society of American Bacteriologists, Association of American. Anatomists, Southern Society for Philosophy and Psychology, the Sullivant Moss Society, and the Wild Fiower Preservation Society.

The address of the retiring president of the association, Prof. E. L. Nichols, of Cornell, was entitled "Science and the Practical Problems of the Future," and was printed in an abridged form in last week's NATURE. It was an address of very broad bearing, written by an eminent physicist and at the same time by one engaged in university work. It contained a strong plea for research work in pure science at the universities. The addresses of the vice-presidents, that is, presidents of sections, were all upon important topics. Vice-president Wilson, before the section of zoology, spoke on recent researches on the determination and heredity of sex; Vice-president Talbot, before the section of chemistry, spoke of science teaching as a career; Vice-president Crowell, before the section of social and economic science, spoke on the influence of science on investments; Vice-president Lovett, in mathematics and astranomy, had for a title "The Problem of Several Bodies: Recent Progress in its Solution ".; Vice-president Miller, before the section of physics, spoke on the influence of the material of wind instruments on the tone quality; Vice-president Bessey addressed the botanists on the subject of the phyletic idea in taxonomy; Vice-president Hektoen, before the section of physiology and experimental medicine, spoke of opsonins and other anti-bodies; Vice-president Boas addressed the section of anthropology and psychology upon the important topic of race problems in America; and Vice-president Landreth, before the section of mechanical science and engineering, spoke of governmental control of public waters.

The addresses all through the meeting assumed in general an aspect of great interest. Dr. Bogert's address as retiring president of the American Chemical Society was on the subject of the function of chemistry in the conservation of natural resources;
Prof. Muensterberg, as president of the American Philosophical Association, spoke on the problem of beauty; the address of the president of the American Society of Naturalists, Prof. Penhallow, of McGill University, was entitled "The Functions of the American Society of Naturalists"; Vice-president Brown, before the section of education, dealt with world standards of education.

The public addresses were of extreme interest. Prof. E. B. Poulton, F.R.S., of the University of Oxford, addressed a large audience on the subject of mimicry in the butterflies of North America; Dr. Albrecht Penck, of the University of Berlin, spoke on the same night before an equally large audience on man, climate, and soil; Mr. W. A. Bryan, of Honolulu, gave a public lecture on a visit to Mount Kilauea, illustrated by moving pictures--this address was appropriate in view of the proposed visit of the association to Hawaii in I9I0. An important feature of the meeting was an address by Major Geo. A. Squier, of the United States Army, before the section on mechanical science and engineering, on the subject of recent progress in aëronautics, which was followed by the decision of the section to devote special attention to the field of aëronautics in its future work.

Several symposia of great interest were held during the meeting. That given under the auspices of the section on social and eeonomic science, on the subject of public health, was listened to by a large audience, and included papers by Dr. Wiley, on the nation's pure food problem; by Dr. Howard, on the economic loss to the people of the United States through insects that carry disease; by Mr. Horace Fletcher, on vital economics; by Prof. Irving Fisher, on the movement for health reform; and by Surgeon-General Wyman, on public health administration. The same sectior. held symposia on tariff reform and on stock exchange regulation. An important symposium was held under the section of physiology and experimental medicine on the regulation of physical instruction in schools and colleges from the standpoint of hygiene. The section on geology held a symposium on the subject of correlation, in which the most eminent geologists of the United States took part, and the section on physics held a session at which papers of general interest to scientific men of other specialities were presented.

Possibly the event of greatest general interest was the Darwin memorial day programme, held on Friday, January I. Prof. E. B. Poulton, F.R.S., was present from England at the invitation of the association to take part in the exercises of the day. Introductory remarks were made by the president of the association, Prof. T. C. Chamberlin, of the University of Chicago, and the following addresses were given :-

The theory of natural selection from the point of view of botany, by Dr. John M. Coulter, of the University of Chicago; fifty years of Darwinism: past and future experimental work bearing on natural selection, by Prof. E. B. Poulton, of Oxford University; the cell in relation to heredity and evolution, by Dr. E. B. Wilson, of Columbia University; the direct effect on environment, by Dr. D. T. MacDougal, of the Carnegie Institution of Washington; the behaviour of unit characters in heredity, by Dr. S. W. E. Castle, of Harvard University; mutation, by Dr. Chas. B. Davenport, of the Carnegie Institution of Washington; adaptation, by Dr. Carl H. Eigenmann, of the Indiana University; recent palæontological evidence of evolution, by Prof. H. F. Osborn, of Columbia University.

These addresses will be published in a memorial volume, together with the following addresses, which were on the programme, but were not read owing to the necessary absence of the authors:- 
Determinate variation, by Dr. Chas. O. Whitman, of the Universitv of Chirago; the isolation factor, by Dr. David Starr Jordan, of Stanford University; evolution and psychology, by Dr. G. Stanley Hall, of Clark University.

At night on Friday, January 1 , a Darwin memorial dinner was given, attended by about 300 naturalists. Following the dinner, addresses were given by Dr. W. H. Welch, on the debt of medicine to Darwin; by $\mathrm{Dr}$. Albrecht Penck, on the geographical factor in evolution; and by Prof. E. B. Poulton, on Darwin's life and character. Prof. Poulton was particularly happy in his address, and his visit to America at this time and for this purpose was a great gratification to all the members of the American Association. At the close of the dinner a congratulatory telegram was sent to Dr. Alfred Russel Wallace.

The association decided to meet in Boston during convocation week, 1909-1o, and the following plans were laid for future meetings: I9I0-11, Minneapolis; summer of I9IO, Honolulu; I9II-I2, Washington; 1912-I3, Cleveland; I9I3 I4, Toronto. The following officers for the coming year were elected :-

President: David Starr Jordan, Stanford University; Vice-presidents: Section A, E. W. Brown, of Yale University; Section B, L. A. Bauer, of Carnegie Institution; Section C, Wm. McPherson, of Ohio State University; Section D, J. F. Hayford, of U.S. Coast and Geodetic Survey; Section E, R. W. Brock, director of the Geological Survey of Canada; Section F, W. E. Ritter, of University of California; Section G, D. P. Penhallow, of McGill University; Section H, Wm. H. Holmes, of Bureau of Ethnology; Section I, Carroll D. Wright, of Clark College; Section K, C. S. Minot, of Harvard University; Section L, James E. Russell, of Columbia University: General Secretary: Dayton C. Miller, of Cleveland; Secretary of the Council: F. G. Benedict, of Carnegie Institution.

Among the resolutions of general interest passed by the council were one protesting against special legislation against vivisection; another requesting Congress to do away with tariff on scientific books, instruments, and apparatus; and a third requesting Congress to enlarge the scope of the National Bureau of Education.

Much pleasure was expressed during the meeting at the very courteous action of the British Association in making the officers of the American Association honorary members for the coming Winnipeg meeting, and in offering to the fellows and members of the American Association membership in the British Association for the meeting on the same terms as old members of the British Association, including the receipt of the report of proceedings of the meeting. It seems certain that there will be a large attendance of members of the American Association at the Winnipeg meeting.

\section{THE PROMOTION OF RESEARCH. ${ }^{1}$}

$T H E$ question of the promotion of research is one which makes a very direct appeal to scientific men, most of whom have at some time or other been confronted with the difficulties raised by it. In a little volume which has reached us a scheme is outlined for the promotion of scientific research, under which public money may be awarded to persons making discoveries prescribed by Parliament. According to the scheme, any person who has made such a discovery may apply for a grant, the application being accompanied by a specification of the discovery. The specification is examined for formalities and for novelty of subject-matter, and afterwards all the specifications accepted in one year are submitted to an investigation

I "A Scheme for the Promotion of Scientific Re earch." By Waiter B. Priest. 2nd edition. Pp. iv +64 . (London: Stevens and Sons, 19o8.) NO. 2047, vOL. 79] as to the nature and novelty of all the discoveries for that year, grants being then made in relation to the discoveries which comply with the terms prescribed by Parliament.

It will be seen from this brief statement of the scheme that it bears a close resemblance to the grant of Letters Patent to inventors, and, in fact, the scheme is based on the Patents Acts. The patent law enables an inventor to obtain a grant, not of money, but of a monopoly, for a limited time, and by somewhat similar procedure the scheme enables a person making a discovery prescribed by Parliament to obtain a grant, not of a monopoly, but of money. There can, unfortunately, be no doubt that many discoverers have hitherto met with very inadequate remuneration, and that some have not been recognised at all. While it is doubtful whether the establishment of such a scheme would enable discoverers to be remunerated adequately, it would certainly provide for the recognition by the State of "true and first discoverers," and to this extent at least would diminish injustice and encourage scientific research. It might also exert a powerful, though indirect, effect on manufacture, for if such a scheme had been established, and if Parliament had prescribed, say, discoveries relating to glass for optical instruments, how different might have been the position to-day of English manufacturers of optical instruments.

The adoption of such a scheme could without doubt be utilised to accelerate the solution of some of the important problems of physical and chemical science, and many of the life and death problems of medical and biological science.

\section{AN INVESTIGATION OF THE SOCIOLOGY AND RELIGION OF THE ANDAMANESE.}

$T$ HE inhabitants of the Andaman Islands have long been recognised as one of the most primitive races of mankind. By their geographical position and their ferocity towards strangers, they were practically isolated from the rest of the world until 1858 . The tribes of the Great Andaman, which constitute by far the largest part of the whole race, are rapidly diminishing in numbers, and are fast forgetting their ancient lore; the next half-century will witness their entire extinction. It was thus highly desirable that a full investigation should be made of these interesting pygmies before it was too late. Through the labours of Mr. E. H. Man and the publications of Sir Richard Temple and Mr. M. V. Portman, a good deal was known concerning the general life of the people, their language, and other subjects, more particularly those of the southern tribes of the Great Andaman. Owing to recent developments in the studies of comparative sociology and religion, it was desirable that Mr. Man's observation should be confirmed and extended.

When the Board of Anthropological Studies in Cambridge was entrusted with the selection of the first Anthony Wilkin student, it had no hesitation in appointing Mr. A. R. Brown, of Trinity College, to undertake this important investigation. He started for the Andamans at the end of August, I906, and spent two dry seasons of six months each at his field work in the jungles of the Andaman Islands. $\mathrm{Mr}$. Brown was able to confirm a great deal of what Mr. Man had written concerning the southern tribes and to supplement this by a thorough study of the northern tribes of the Great Andaman.

Measurements on the living subjects prove the Andamanese to be a very homogeneous race, with little variation and a strongly marked racial type. In 